\title{
Zihinsel Yetersizliğe Sahip Çocukların Annelerinin Yaşadıkları Güçlükler ve Başa Çıkma Stratejileri Hakkındaki Görüşleri
}

\section{Difficulties of Mothers of Children With Intellectual Disabilities and Their Opinions About Coping Strategies}

\author{
Serap Bayram ${ }^{\text {a, }}$, Anıl Görkem ${ }^{\text {b }}$ \\ a Uzm. Mağusa Özel Eğitim Merkezi, Mağusa, KKTC \\ ORCID: 0000-0002-1962-2083

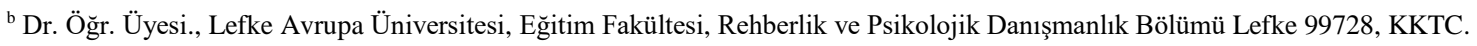 \\ ORCID: 0000-0003-1532-1360
}

\section{MAKALE BILGİSI}

\section{Makale Geçmişi:}

Başvuru tarihi: 31 Mayıs 2019

Düzeltme tarihi: 21 Ekim 2019

Kabul tarihi: 01 Kasım 2019

\section{Anahtar Kelimeler:}

Zihinsel yetersizlik

Güçlükler

Başa çıkma
ÖZ

Araştırmada, zihinsel yetersizliğe sahip çocuğu olan annelerin yaşadığ 1 güçlükler ve başa çıkma yöntemleri araștırılmıștır. Katılımcılar; zihinsel yetersizliğe sahip çocuğu olan anneler arasından maksimum çeşitlilik ve gönüllülük ilkesine göre 15 anne seçilmiştir. Veri toplamada, Kişisel Bilgi Formu ve Yarı Yapılandırılmış Görüşme soruları kullanılmıştır. Araştırmada nitel araştırma yönteminden, durum araştırması deseni uygulanmıştır. Verilen çözümlenmesi ve analizinde betimsel analiz yöntemi uygulanmıştır. Bulgulara göre anneler en çok psikolojik alanda ve eğitim alanında sorun yaşadıklarını belirtmişlerdir. Annelerin en çok kullandığı başa çıkma yöntemi problem odaklı başa çıkma yöntemi olmuştur. Annelerin kullandıkları başa çıkma yöntemleri sorun alanlarına göre değișim gösterdiği, Problem odaklı başa çıkma yöntemlerinden aktif başa çıkma ve yararlı sosyal destek kullanımı, duygu odaklı başa çıkma yöntemlerinde ise kabullenme ve duygusal destek kullanımı olmuștur.

\section{A B S T R A C T}

In this study, the topic being investigated is the problems experienced by mothers who have a child with an intellectual disability and how they are coping with these issues. 15 mothers participated in this study and Mothers who participated in this study were chosen according to maximum diversity method and they all consented voluntarily to participate in this study. The research methods included in this study include a Personal Information Questionnaire and Semi Structured Individual Interview. A qualitative research method and a case study design were used. The descriptive analysis method was used to analyse to obtained data. According to the results of the research, mothers stated that their major problems are in psychological and education fields. The most commonly used methods of coping by mothers are problem-focused coping. The most frequently used problem-focused coping methods are; active coping and the use of instrumental social support, while the most commonly used emotion-focused coping methods are acceptance and seeking of emotional social support.

\section{Giriş}

Çocuk sahibi olmak anne babanın hayatında birçok değişikliği beraberinde getirmekte, ailenin bu değişikliğe uyum göstermesi ve hayatında düzenlememeler yapması gerekmektedir. Anne babalar çocuk sahibi olmaya karar verdiklerinde hayatlarında oluşacak değişiklikleri; umut, heyecan ve yolunda gitmeyebilecek durumlar için biraz da kaygı ile beklerler. Normal gelişen bir çocuğa sahip olmakla ilgili beklentileri ve hayalleri olan anne baba, yetersizliği olan bir çocuk sahibi olduklarında hayal kırıklığına uğramakta ve çocuk sahibi olma ile ilgili süreçlere uyum sağlamada daha fazla güçlük yaşamaktadırlar. Normal gelişen çocuğa sahip anne babaların aldığı sorumluluklar bile

\footnotetext{
* Sorumlu yazar/Corresponding author.

e-posta: asayilir@eul.edu.tr
} 
yorucu olabilirken, zihinsel yetersizliği olan bir çocuğa sahip olmak ailenin yükünü daha da artırmakta ve anne babalar uyum sağlamak için daha fazla çaba göstermek zorunda kalmaktadırlar (Üskün ve Gündoğar, 2013).

Anne babanın zihinsel yetersizlik yaşayan çocuğun doğumuyla oluşan tepkileri; şok, üzüntü, kızgınlık, inkar etme, suçluluk duyguları, kaygı, çeşitli krizler, çevrenin tutumuyla yüz yüze gelmekten kaçınma, hayal kırıklığı, kendine güven ve saygı duymada azalma gibi farklı tutum ve davranışlar olabilmektedir (Akandere, Acar, ve Baştuğ, 2009). Zihinsel yetersizliği olan bir çocuğa sahip olmak, hayatın birçok alanında sorunlara yol açmaktadır.

$\mathrm{Bu}$ güçlükler, psikolojik, aile içi ilişkiler, sosyal çevre ile ilişkiler, ekonomik ve eğitimle ilgili güçlükler olarak sıralanabilir. $\mathrm{Bu}$ güçlükler ailenin tüm üyelerini etkilemektedir, ancak anneler çocukla ilgili oluşan sorunlarda ve bunlara çözüm bulunmasında daha aktif olarak rol almakta ve daha çok çaba göstermektedirler (Dönmez, Bayhan ve Artan, 2000). Bunun başlıca nedeni annelerin çocuğun ihtiyaçlarını gidermede birincil kişi olarak görülmeleri ve çocuklarıyla güçlü bir duygusal bir bağ kurmaları, diğer nedeni ise annelerin çocukla daha fazla zaman geçirmeleri ve bu nedenle daha fazla stres ve sorumluluk hissetmeleridir (Rowbotham, Carroll, Cuskelly, 2011). Bu stres ve sorumluluk duygusunu artıran nedenler çoğaldıkça yaşanan güçlükler de artmaktadır.

Hayatın akışı içerisinde bireyi değişim ve daha fazla çaba göstermeye zorlayan durumlar bireyde stres yaratır. Stres yaratan olaylar karşısında uygun başa çıkma yöntemlerini kullanan bireylerin yaşam doyum seviyesinin daha yüksek olduğu görülmüştür (Deniz, 2006).

Zihinsel yetersizliği olan çocukların annelerin kaygı düzeylerinin sağlıklı çocuğa sahip annelerden önemli oranda yüksek olduğuna işaret edilmiştir (Uğuz, Toros, İnanç ve Çolakkadıoğlu, 2004). Bir diğer araştırma sonucuna göre anneler, yetersizliği olan çocuğun bakımı ve normal aile içinde aldıkları sorumluluklar nedeniyle daha fazla sıkıntı yaşamakta ve depresyona girme olasılıkları daha yüksek olmaktadır (Demir, Özcan ve Kızılırmak, 2010). Annelerin içinde bulunduğu psikososyal risklerin fazla olması nedeniyle bu araştırma annelerin yaşadığı stres ve güçlükler üzerinde durmaktadır. Zihinsel yetersizliği olan bir çocuğa sahip olmak yaşamın hangi alanlarında daha fazla stres ve sorumluluk yaratmaktadır? Sorunların artması anneleri nasıl etkilemektedir? Anneler güçlükler karşısında nasıl bireysel yanıtlar vermektedirler? $\mathrm{Bu}$ yanıtları başa çıkma davranışlarını nasıl etkilemektedir ve kendilerine nasıl yardımcı olmaktadır? gibi sorular bu araştırmanın temel başlangıç noktaları olmuştur.

Zihinsel yetersizliği olan çocuklarla yapılan son çalışmalar göstermiştir ki; eğitim hizmetleri, yetersizliği olan çocuklarla sınırlandırılmamalı, diğer aile bireylerine de ihtiyaç duydukları konularda hizmet verilmelidir (Köksal, 2011). Araştırmalar annelerin zihinsel yetersizliği olan bir çocuğa sahip olmakla ilgili çeşitli sıkıntılar yaşadığını göstermektedir fakat bu sıkıntı ve güçlüklerin neler olduğunun bilinmesi onlara sunulacak yardım ve destek programları için önemlidir. Ayrıca bireylerin öz kaynakları ve çevresel kaynakları hakkındaki düşünceleri, stresle ve güçlüklerle başa çıkmada bu kaynakları nasıl kullandıkları da önem arz etmektedir. Bu araştırmada zihinsel yetersizliğe sahip çocuğu olan annelerin yaşadıkları güçlükler ve başa çıkma yöntemlerini incelemek amaçlanmıştır.

Yetersizliğe sahip çocuğun varlığı ailelerde bazı duygusal tepkiler yaratmaktadır. Bu duygusal tepkileri genel olarak açıklamak için çeşitli modeller geliştirilmiştir. Bunların arasında aşama modeli en kabul görenidir (Doğan, 2001). Aşama modeline göre yetersizliği olan çocuğa sahip ebeveynler önce başlarına gelen duruma inanmakta güçlük yaşamakta, şok geçirmektedirler. $\mathrm{Bu}$ aşamanın ardından ebeveynler önce durumu reddetme, sonra durumu tanıma süreçlerinden geçerler. Durumu tanıma sürecinde ebeveynler; öfke, depresyon, suçluluk ve utanç gibi karmaşık duygular yaşarlar. Bunun sonrasında pazarlık aşaması başlar ve bu süreçte aile kendine yardımcı olacak kişi, kurum ve hizmetleri araştırmaya başlar. $\mathrm{Bu}$ aşamaları atlatan ebeveynler uyum aşamasına geçerler. Uyum aşamasında ebeveynler kaygı yaşasalar da durumla daha işlevsel biçimce baş etmeye çalışırlar ve yaşamlarını yetersizlik yaşayan çocuklarına göre düzenlemeye çalışırlar (Doğan, 2001).

Özellikle yetersizliğe sahip çocuğu olan annelerle ilgili yapılan araştırmalarda; annelerin yaşadığı olumsuz duygulara örnek olarak, umutsuzluk (Zembat ve Y1ldız, 2010), suçluluk (Keskin, Bilge, Engin ve Dülgerler, 2012), utanç (Keskin vd., 2012) ve tükenmişlik duyguları (Çengelci, 2009) gösterilebilir. Buna ek olarak depresyona girme (Meirsschaut, Roeyers ve Warreyn, 2010) ve kayg1 (Uğuz vd., 2004) seviyeleri de normal gelişen çocuğu olan annelerden önemli oranda yüksek bulunmuştur. Yaşanan stresin yükselmesi, algilanan sosyal desteğin düşmesi (Kaner, 2004) ve kaygı düzeyinin yüksek olmasının (Deniz, Dilmaç, Arıcak, 2009) anne babaların yaşamdan aldıkları doyumu azalttığı saptanmıştır. Ayrıca zihinsel ve bedensel yetersizliğe sahip çocuğu olan annelerin, böyle çocuğu olmayan annelere göre depresyon ve anksiyete düzeylerinin daha yüksek olduğu bulunmuştur (Uğuz vd., 2004).

Stres bireyin yaşam olayları karşısında zorlanması demektir. Başa çıkma ise zorlanmaya neden olan durumlara bireyin yanıt verme şekli olarak tanımlanmaktadır (Ayyıldız, Şener, Kulakçı ve Veren, 2012). Lazarus, ve Folkman'a göre (1984), başa çıkma yöntemleri problem odaklı ve duygu odaklı yöntemler olarak ikiye ayrılmaktadır. Problem odaklı başa çıkma yöntemleri genellikle sorun yaratan durumu değiştirmeye dönük aktif çabaları, duygu odaklı yöntemler ise inkar ve durumdan uzaklaşmaya çalışma gibi yöntemlerdir. Stres yaratan olaylar karşısında uygun başa çıkma yöntemlerini kullanan kişilerin yaşam doyum düzeylerinin daha yüksek olduğu belirtilmiştir (Deniz, 2006). Problem odaklı başa çıkma yöntemlerini kullanan anne babaların durumluk ve sürekli kaygı düzeyleri problem odaklı yöntemleri kullanmayanlara göre daha düşük olmaktadır (Keskin vd., 2012).

$\mathrm{Bu}$ çalışmada; zihinsel yetersizliğe sahip çocukların annelerinin yaşadıkları güçlükler ve bu sorunlarla nasıl başa çıktıkları araştırılmıştır. Annelerin; zihinsel yetersizlik durumu ile ilgili yaşadıkları güçlükler; başlıklar (psikolojik, aile, yakın çevre, eğitim, ekonomik) altında incelenmiş ve hangi başa çıkma stratejilerini kullandıkları öğrenilmeye çalışılmıştır. 
Zihinsel yetersizliğe sahip çocuğu olan annelerle ilgili yapılan araştırmalarda annelerin yetersizliği olan çocuğun bakımında daha fazla rol aldıkları ve bakım yüklerinin eşlerinden daha fazla olduğu saptanmıştır (Hedov, Anneren ve Wikblad, 2000). Yetersizliği olan çocukların annelerin hem ev içinde aldıkları sorumluluklar hem de çocuğun bakım ihtiyaçlarını karşılama gibi yüklerden dolayı depresyona girme riskleri daha diğer annelerden daha yüksektir (Demir vd., 2010). Bu bulgu annelerin psikolojik olarak daha fazla risk altında olduklarını, özellikle psikososyal desteğe daha fazla ihtiyaç duyduklarını göstermekte, durumlarının daha yakından izlenmesi ve duygusal paylaşımda bulunmalarına imkan verilmesinin gerektiğine işaret etmektedir (Kaçan-Softa, 2013; Şengül ve Baykan, 2013). Annelerin bakım yükünün ve sorumluluklarının babalardan daha fazla olması nedeniyle, öncelikli olarak anneler hakkında bilgi sahibi olmak istenmiş ve bu araştırmada anneler üzerinde durulmuştur.

$\mathrm{Bu}$ araştırmada zihinsel yetersizliğe sahip çocuğu olan annelere verilecek psikolojik desteğin şekillendirilmesinde esas alınacak konular ve sorun alanları hakkında durulmuş, ayrıca annelerin zihinsel yetersizlik anlaşıldığı andan bugüne kadar kullandığ olan faktörler gibi konular incelenerek başa çıkmada yardımcı olan ve olmayan faktörler hakkında bilgi sahibi olunmak istenmiştir. Araştırmada toplanan bilgiler ile annelerin yaşadığ güçlükler incelenerek kendilerine hizmet ve yardım veren kurum ve kuruluşlardaki görevliler ve psikolojik yardım uzmanlarına yardım konuları hakkında bilgi oluşturulmaya çalışılmıştır. Zihinsel yetersizliği olan bir çocuğa sahip olmakla ilgili baş etme becerileri yüksek oranda öznel bir süreçtir ve bazı aileler yetersizliği olan bir çocuk sahibi olma durumuna tam bir uyum gösteremeyebilirler. $\mathrm{Bu}$ durumda annelerin ne tür süreçlerden geçtikleri ve hangi başa çıkma becerilerini kullandıkları ve kullanmadıkları daha fazla önem kazanmaktadır.

\subsection{Araştırmanın Problemi}

Araştırmanın problemi, Annelerin zihinsel yetersizliği olan bir çocuğu olmakla ilgili yaşadıkları sorunlar ve güçlükler nelerdir?'dir. Sonuçların ilk bölümünde araştırmanın ilk alt problemi olan "Zihinsel yetersizliğe sahip çocuğu olan annelerin bununla ilgili yaşadıkları sorunlar ve güçlükler nelerdir?" sorusuna cevap alınacaktır. Giriş olarak genel sorun alanlarının yüzdeleri açıklandıktan sonra 5 madde olarak alt sorun alanları gösterilmiştir. Bunlar; Annenin yaşadığı psikolojik güçlükler, Annenin eşi ve diğer çocuklarıyla yaşadığı güçlükler, Annenin yakın çevre (geniş aile, akrabalar, komşular, tanıdıklar) ile yaşadığı güçlükler, Annenin eğitimle ilgili yaşadığı güçlükler, Annenin yaşadığı ekonomik güçlükler'dir.

\subsection{Araștırmanın Amacı}

$\mathrm{Bu}$ araştırmanın amacı Zihinsel Yetersizliğe Sahip Çocuklarin Annelerinin Yaşadiklari Güçlükler ve Başa Çikma Stratejileri Hakkindaki Görüşlerini belirlemek olarak belirlenmiştir.

\section{Yöntem}

\subsection{Araștırma Modeli}

Araştırma modeli; zihinsel yetersizliği olan çocukların annelerinin yetersizliği olan bir çocuğa sahip olmakla ilgili yaşadıkları güçlükler ile bu güçlükleri aşarken hangi başa çıkma yollarını kullandıklarını öğrenmek için oluşturulmuş yarı yapılandırılmış görüşme sorularına dayalı olarak nitel desende kurgulanmıştır. Araştırmada örnek olay (durum) araştırması deseni kullanılmıştır. Elde edilen verilere zihinsel yetersizliğe sahip çocuğu olan 15 anne ile yapılan yarı yapılandırılmış görüşmelerden elde edilen sonuçlar ile ulaşılmıştır. Görüşme soruları ile annelerden zihinsel yetersizliği olan bir çocuğa sahip olmakla ilgili yaşadıkları güçlük ve bu sorunlarla nasıl başa çıktıkları hakkında bilgi toplanmıştır. Görüşme formunun yanısıra annelerle ilgili bilgi toplamak için 26 maddelik kişisel bilgi formu uygulanmıştır. $\mathrm{Bu}$ formda anne ile ile ilgili bilgiler ve zihinsel yetersizliğie sahip çocuğu ile ilgili bilgiler sorulmuştur.

\subsection{Evren ve Örneklem}

$\mathrm{Bu}$ araştırmanın amacına uygun olarak seçilebilecek yöntemlerden olan maksimum çeşitlilik yöntemine göre örnekleme işlemi yapılmış ve katılımcı anneler seçilmiştir. Yıldırım ve Şimşek (2008)'e göre bu örnekleme yönteminin kullanılmasının amacı; göreceli olarak küçük bir örneklem oluşturmak ve oluşturulan örneklemde çalışılan bireylerin çeşitliliğini maksimum derecede yansitmaktır. $\mathrm{Bu}$ araştırmada çeşitlilik; annenin yaşı, çocuğun yaşı, çocuğun tek veya çoklu yetersizliğe sahip olma faktörleri dikkate alınarak sağlanmaya çalışılmıştır. Annelerin yaşı 31 ve 55 yaşları arasında, yetersizliği olan çocukların yaşları 6-17 arasında değişmektedir. Araştırmaya katılan annelerin 9 tanesinin çocuğunda sadece zihinsel engel bulunmakta, 6 tanesinin çocuğunda ise hem zihinsel hem de bedensel engel birlikte bulunmaktadır.

Araştırma, K.K.T.C.'de Gazimağusa ve İskele bölgesinde ikamet eden ve çocuğu bir özel eğitim kurumuna devam eden annelerle gerçekleştirilmiştir. Araştırmanın örneklemi, Gazimağusa Özel Eğitim Merkezinde eğitim gören zihinsel yetersizliği olan çocukların annelerinden gönüllü olanlar ile oluşturulmuştur.

Araştırmanın katılımcılarını belirlemek amacıyla, K.K.T.C. Milli Eğitim ve Kültür Bakanlığına bağlı Psikolojik Danışmanlık, Rehberlik ve Araştırma Şubesi'ne başvurulmuş Gazimağusa ve İskele bölgesinde ikamet eden ve bir kuruma devam eden zihinsel yetersizliği olan çocuklar hakkında bilgi danışılmış ilgili okul ve kurumlar hakkında bilgi alınmıştır. Gazimağusa Özel Eğitim Merkezi hem Gazimağusa hem de İskele bölgesinden öğrenci kabul etmektedir. $\mathrm{Bu}$ kurum, araştırmanın katılımcılarının seçileceği yer olarak seçilmiştir. Anneler hakkında okuldan bilgi edinilmiş ve araştırmaya katılacak anneler, Zihinsel yetersizliği olan çocuğu olmak, Zihinsel yetersizliği olan çocuğunun 3-18 yaşları arasında olması, Annenin okuma yazma bilmesi, Zihinsel yetersizliği olan çocuğunun bir tıbbi tanısı veya ilgili bakanlık tarafından düzenlenmiş eğitsel yönlendirme raporunun bulunması önkoşulları dikkate alınarak belirlenmiştir. 
Araştırmanın yapılabilmesi için, K.K.T.C. Milli Eğitim ve Kültür Bakanlığı ilköğretim dairesi müdürlüğüne resmi yazı yazılarak araştırmanın konusu, amacı ve sorulacak sorularla ilgili bilgi verilmiş, gerekli onay ve izin alınmıştır. Araştırma, zihinsel yetersizliğe sahip çocuğu olan 15 anne ile gerçekleştirilmiştir.

Katılımcıların demografik bulgularına ilişkin bilgiler ise Tablo 1'de verilmiştir.

Tablo 1. Demografik Bulgulara İlişkin Bilgiler

\begin{tabular}{|c|c|c|c|}
\hline Değişkenler & Değişkenler & $\mathbf{n}$ & $\%$ \\
\hline \multirow[t]{5}{*}{ Yaş } & $31-35$ & 5 & 33 \\
\hline & $36-40$ & 4 & 27 \\
\hline & $41-45$ & 4 & 27 \\
\hline & $46-50$ & 0 & \\
\hline & $51-55$ & 2 & 13 \\
\hline \multirow[t]{3}{*}{ Eğitim Durumu } & İlkokul & 9 & 60 \\
\hline & Ortaokul & 3 & 20 \\
\hline & Lise & 3 & 20 \\
\hline \multirow[t]{2}{*}{ Uyruğu } & K.K.T.C. & 13 & 87 \\
\hline & T.C. & 2 & 13 \\
\hline \multirow[t]{3}{*}{ Medeni Durumu } & Bekar & 0 & \\
\hline & Evli & 15 & 100 \\
\hline & Boşanmış & 0 & \\
\hline \multirow{4}{*}{$\begin{array}{l}\text { Ailede Kaç Kişi } \\
\text { Yaşıyor? }\end{array}$} & 3 & 2 & 13 \\
\hline & 4 & 8 & 53 \\
\hline & 5 & 4 & 27 \\
\hline & 6 & 1 & 7 \\
\hline \multirow{5}{*}{$\begin{array}{l}\text { Annenin kaç çocuğu } \\
\text { var? }\end{array}$} & 1 & 1 & 7 \\
\hline & 2 & 9 & 60 \\
\hline & 3 & 3 & 20 \\
\hline & 4 & 0 & \\
\hline & 5 & 2 & 13 \\
\hline \multirow[t]{2}{*}{$\begin{array}{l}\text { Aile ile birlikte } \\
\text { yaşamayan çocuk sayısı }\end{array}$} & Yok & 13 & 87 \\
\hline & Var & 2 & 13 \\
\hline \multirow[t]{4}{*}{ Ailenin Gelir Durumu } & Düşük & 7 & 47 \\
\hline & Orta & 7 & 47 \\
\hline & İyi & 1 & 7 \\
\hline & Çok İyi & 0 & \\
\hline \multirow[t]{2}{*}{$\begin{array}{l}\text { Ailede başka engelli } \\
\text { birey var mı? }\end{array}$} & Yok & 11 & 73 \\
\hline & Var & 4 & 27 \\
\hline \multirow[t]{2}{*}{$\begin{array}{l}\text { Annenin Aldığı } \\
\text { Psikolojik Yardım }\end{array}$} & Var & 3 & 20 \\
\hline & Yok & 12 & 80 \\
\hline \multirow[t]{3}{*}{$\begin{array}{l}\text { Genel Olarak Kendinizi } \\
\text { Nasıl Hissediyorsunuz? }\end{array}$} & Rahat & 7 & 47 \\
\hline & Zor Durumda & 8 & 53 \\
\hline & $\begin{array}{l}\text { Çok Zor } \\
\text { Durumda }\end{array}$ & 0 & \\
\hline
\end{tabular}

\subsection{Veri Toplama Aracı}

Veri toplama tekniği olarak kişisel bilgi formu ve yarı yapılandırılmış görüşme tekniklerinden yararlanılmışıtır. Önce araştırma kapsamına alınacak annelerle ilgili veri toplamak için bir kişisel bilgi formu oluşturulmuştur. Daha sonra görüşme soruları hakkında çalışılmış, araştırmanın konusu ve amacı ile ilgili yayınlar, ulusal ve uluslararası akademik yayınlar başlığı altında incelenmiş ve değerlendirilmiştir. Kavramsal çerçeve oluşturulduktan sonra görüşme formunda bulunması düşünülen ölçütler ve sorular belirlenmiştir. $\mathrm{Bu}$ sorular alandaki uzmanlarca değerlendirilmiş ve ilgili ekleme ve düzeltmeler yapılmıştır. Görüşme formunda ise temel olarak 5 başlık incelenmiştir. $\mathrm{Bu}$ başlıklar altında annelerin yaşadığı psikolojik sorunlar, aile içi sorunlar, yakın çevre ile yaşanan sorunlar, eğitimle ilgili yaşanan sorunlar ve ekonomik sorunlar incelenmiş; yaşanan sorun alanları ile annelerin hangi yöntemleri kullanarak başa çıktığı araştırılmıştır.

\subsection{Verilerin Analizi}

Araştırmanın değerlendirilme aşamasında "betimsel analiz" yöntemi uygulanmıştır. $\mathrm{Bu}$ yönteme göre elde edilmiş veriler, önceden belirlenmiş temalar çerçevesinde özetlenip ve yorumlanır ve birtakım sonuçlara ulaşılarak anlamlandırılır (Yıldırım ve Şimşek, 2004:171-172). Verilerin incelenmesi şu sıra ile gerçekleştirilir; "betimsel analiz için bir çerçeve oluşturulması, tematik çerçeveye göre verilerin işlenmesi, bulguların tanımlanması ve yorumlanması" (Altunışık, Coşkun, Bayraktaroğlu ve Y1lirim, 2010; s:322)

Katılımcı annelerin kimliklerini gizlemek ve verilerin okunmasını kolaylaştırmak amacıyla katılımcı annelere kod numaraları verilmiştir (A1, A2, A3,...). Alınan ses kayıtları da aynı şekilde isimlendirilmiştir. Sonra yapılan görüşmeler MS Word programında deşifre edilmiş, bunlar da aynı kod numaraları ile ayrılmıştır. Ses kayıtları dinlenilerek ve metin dosyaları incelenerek annelerin hangi alanlarda sorun yaşadığı, ne tür sorunlar yaşadığı, bunlarla baş etmek için hangi başa çıkma yöntemlerini kullandıkları, bu başa çıkma yöntemlerinin araştırmada incelenen başa çıkma yöntemlerinden hangi sınıflandırmaya girdiği derinlemesine incelenmiştir. Daha sonra elde edilen veriler doğrultusunda bir tematik çerçeve kurulmuş, buna göre yanıtlar tekrar incelenerek frekanslar toplanmış, yüzdelere çevrilmiş ve verilerin işlenmesi ve bulguların tanımlanması aşamaları gerçekleştirilmiştir. Böylece veriler, yaşanan sorunlar ve başa çıkma yöntemleri çerçevesinde incelenmiştir. Annelerin ifadelerinden alıntılara yer verilerek tematik analiz ile verilen cevaplar arasında bağlantı kurulmaya çalışılmıştır. Daha sonra ulaşılan bulgulara yer verilmiş, bulgular yorumlanarak veri analizi tamamlanmıştır.

\section{Bulgular ve Yorumlar}

Bu bölümde "Annelerin zihinsel yetersizliği olan bir çocuğu olmakla yaşadıkları sorunlar ve güçlükler” ile ilgili bulgular ve yorumlar yer almaktadır.

3.1. Annelerin Zihinsel Yetersizliği Olan Bir Çocuğu Olmakla İlgili Yaşadıkları Sorunlar Ve Güçlükler Nelerdir?

Bulguların ilk bölümünde araştırmanın ilk alt problemi olan "Zihinsel yetersizliğe sahip çocuğu olan annelerin bununla ilgili yaşadıkları sorunlar ve güçlükler nelerdir?" sorusuna cevap alınacaktır. Giriş olarak genel sorun alanlarının yüzdeleri açılandıktan sonra 5 madde olarak alt sorun alanları gösterilmiştir. 
Tablo 3.1. Genel Sonuçlar

\begin{tabular}{|c|c|c|}
\hline Sorun Alanları & $\begin{array}{l}\text { Sorun Yaşayan } \\
\text { Anne Sayısı }\end{array}$ & $\%$ \\
\hline $\begin{array}{l}\text { Psikolojik Güçlükler } \\
\text { Eğitimle İlgili Güçlükler } \\
\text { Ekonomik Güçlükler } \\
\text { Aile İçi Güçlükler } \quad \text { (Eş } \quad \text { ve } \\
\text { Kardeşleri) }\end{array}$ & $\begin{array}{l}15 \\
15 \\
12 \\
7\end{array}$ & $\begin{array}{l}100 \\
100 \\
80 \\
47\end{array}$ \\
\hline Yakın Çevre İle İlgili Güçlükler & 6 & 40 \\
\hline
\end{tabular}

Sonuçlara çoktan aza şeklinde sıralanıp bakıldığında annelerin en çok psikolojik ve eğitimle ilgili alanlarda sorun belirttikleri görülmüştür. Tüm anneler bu alanlarda sorun yaşadıklarını belirtmiştir. $\mathrm{Bu}$ sorun alanlarını sırasıyla ekonomik güçlükler, aile içi güçlükler ve yakın çevre ile ilgili güçlükler takip etmektedir. Annelerin sorunlarına bakıldığında temel sorunlarının psikolojik sıkıntılar, eğitimle ilgili güçlükler ve ekonomik güçlükler olduğu görülmüştür. Anneler aile içi ve çevre ile ilgili sorunlarından daha az bahsetmişlerdir. Annelerin yaşadığı psikolojik güçlüklere bakıldığı zaman sonuçlar Tablo 3.2'de belirtilmektedir.

Tablo 3.2. Annelerin Yaşadıkları Psikolojik Güçlükler

\begin{tabular}{llll}
\hline S.N. & \multicolumn{1}{c}{ Psikolojik Güçlükler } & f & \% \\
\hline $\mathbf{1}$ & Üzüntü, S1kıntı, Stres & 14 & 93 \\
$\mathbf{2}$ & Şaşırma, şok & 13 & 87 \\
$\mathbf{3}$ & Kabullenmeme & 8 & 53 \\
$\mathbf{4}$ & Belirsizlik, Bilgisizlik, & 4 & 27 \\
& Gelecek Kaygısı & & \\
$\mathbf{5}$ & Kendini Sorumlu Tutma & 3 & 20 \\
$\mathbf{6}$ & Yalnızlı & 2 & 13 \\
$\mathbf{7}$ & Depresyon & 1 & 7 \\
\hline
\end{tabular}

Psikolojik sorun alanlarına incelendiğinde annelerin çocuklarının yetersizliğe sahip oluşlarıyla ilgili en çok belirttikleri güçlükler; üzüntü, sıkıntı, stresle ilgili güçlükler olmuştur. Konu ile ilgili olarak A2 kodlu anne" Çok şaşırdım, üzüldüm, biraz psikolojim de bozuldu, olaylar biraz geçtikten sonra niye ben? niye çocuğum? diye bayağ 1 bir üzüntü yaşadım. Kendimi ancak bir ayda toparlayabildim. Daha doğrusu toparlamak zorunda kaldım, çünkü çocuğuma bakmak ve ilgilenmek zorundaydım." şeklinde görüşlerini belirtmiş, A7 ise, "Psikolojim bozulduğu an ağlıyorum, kimisi vurur, kırar, ben ağlıyorum. Belki eziklik ama ben böyle kendimi ifade ediyorum" şeklinde duygusal tepkilerini ifade etmiştir.

\subsection{Annenin Eşi ve Diğer Çocuklarıyla Yaşadığı Güçlükler}

Tablo 3.3. Annelerin Eşi ve Diğer Çocuklarıyla Yaşadığı Güçlükler

\begin{tabular}{lllll}
\hline S.N. & $\begin{array}{l}\text { Eş ve Diğer Çocuklarla } \\
\text { Yaşanan Güçlükler }\end{array}$ & f & \% \\
\hline $\mathbf{1}$ & $\begin{array}{l}\text { Eşin İlgisizliği ve Çocuğu } \\
\text { Reddetmesi }\end{array}$ & 4 & 27 \\
$\mathbf{2}$ & $\begin{array}{l}\text { Kardeş K1skançlığı, Kardeş ile } \\
\text { Geçimsizlik }\end{array}$ & 3 & 20 \\
$\mathbf{3}$ & Eşlerin Birbirini Suçlaması & 3 & 20 \\
\hline
\end{tabular}

Eş ve çocuklarla yaşanan güçlükler; tüm sorun alanları içinde 4. sırada gelmektedir. Kişisel bilgi formlarından elde edilen veriye göre annelerin \%70'i yetersizliği olan çocuğun bakımında eş ve diğer çocuklarından aldığı desteği "orta düzeyde" ve "çok yardım alıyorum" şeklinde ifade etmiştir. A11 eşinin ilgisizliği ile ilgili düşüncelerini "Babalarının disiplin uygulamasını çok isterdim. Çocukların birinden çekinmesini isterdim. Ne zaman bunu eşime söylesem, 'çocukları sen eğitirsin, sen yetiştirirsin, bana bir şey söyleme' der. Halbuki onun devreye girmesini beklerdim" şeklinde belirtmiştir. A11, "Eşimin kabullenmesi zor oldu. Hala da tam kabullenmiş değil”" demiştir.

\subsection{Annelerin Yakın Çevre ile Yaşadığı Güçlükler}

Tablo 3.4. Annelerin Yakın, Arkadaş ve Akrabalarıyla Yaşadığı Güçlükler

\begin{tabular}{|c|c|c|c|c|}
\hline S.N. & $\begin{array}{l}\text { Annelerin Yakın, Arkadaş ve } \\
\text { Akrabalarıyla Yaşadığı Güçlükler }\end{array}$ & & $\mathbf{f}$ & $\%$ \\
\hline 1 & Sosyal Çevrenin Azalması & & 3 & 20 \\
\hline 2 & $\begin{array}{l}\text { Kaynana Tarafindan Suçlanma } \\
\text { Çocuğu Reddedilmesi }\end{array}$ & ve & 2 & 13 \\
\hline 3 & Çevrenin Anlayışsızlığ1 & & 1 & 7 \\
\hline
\end{tabular}

Annelerin en düşük oranda sorun belirttiği alan, yakın çevre ile ilgili olan sorunlardır. Bu alanda anneler en çok sosyal çevrenin azalması ve sosyal faaliyetlerinin kısıtlanmasını sorun olarak sunmuş, 2 anne kaynanalarıyla yoğun problemler yaşadığını belirtmiş, 1 anne ise çevreyi anlayışsız bulduğunu ifade etmiştir.

A10, kaynanası ile yaşadığı sıkıntıyı "Kayınvalidem beni suçladı, iyi bakamadın dedi "şeklinde açıklamıştır. A11 geniş ailesinin tepkisini;" Genel olarak ailede acıma hep var. Benim anne babam ve eşimin anne babasında da var. Çocuğun davranışları hakkında 'ay yapmasın, ay niye böyle oldu, niye bağırır?, ben bu çocuğu gördüğüm zaman dayanamamam', derler. "Teyzemin şekeri düşer, tansiyonu yükselir" diyerek ifade etmiştir.

\subsection{Annenin Eğitimle İlgili Yaşadığg Güçlükler}

Tablo 3.5. Annenin Eğitimle İlgili Yaşadığı Güçlükler

\begin{tabular}{|c|c|c|c|}
\hline S.N. & Eğitimle İlgili Güçlükler & f & $\%$ \\
\hline 1 & $\begin{array}{l}\text { Okul ve ögretmen sayıs } \\
\text { yetersizliği }\end{array}$ & 10 & 67 \\
\hline 2 & $\begin{array}{l}\text { Olumsuz Öğretmen } \\
\text { tutumu }\end{array}$ & 6 & 40 \\
\hline 3 & $\begin{array}{l}\text { Normal okullarda kabul } \\
\text { sorunları yaşama }\end{array}$ & 6 & 40 \\
\hline 4 & Bilgisizlik & 4 & 27 \\
\hline 5 & $\begin{array}{l}\text { Farklı eğitim olanaklarının } \\
\text { olmaması }\end{array}$ & 4 & 27 \\
\hline 6 & $\begin{array}{l}\text { Sağlık sorunlarının eğitimi } \\
\text { aksatması }\end{array}$ & 3 & 20 \\
\hline 7 & Okulun eve uzak olması & 2 & 13 \\
\hline
\end{tabular}

Araştırmaya katılan tüm anneler eğitim alanında sorun yaşamış olduklarını belirtmişlerdir. 10 anne okul ve öğretmen sayısını yetersiz bulmakta, 6 anne çocuğunu normal okula yazdırmak istediğinde sorun yaşadığını belirtmektedir. Bazı anneler okulların çocuğu okula kayıt etmek istemediğini, bazı öğretmenlerin tutumlarının kendilerini rahatsız ettiğini belirtmişlerdir. Bunun dişında zihinsel yetersizlik tanısı ilk koyulduğunda eğitimle ilgili ne yapacaklarını bilemediklerini, özel eğitim okullarının varlığını ve nerede olduklarını bilmediklerini belirtmişlerdir. Birkaç anne, tesadüfen okullardan haberdar olduğunu 
belirtmiștir. Bazı anneler ise başka yerlerde farklı eğitim olanakları olduğunu duyduklarını (yüzme, at terapisi vb.) fakat bunları yaşadıkları yerde bulamadıklarını söylemişlerdir.

6 anne, tanı konduktan sonra ücretli olarak özel eğitim desteği aldıklarını söylemişlerdir. Araştırmaya katılan tüm anneler Milli Eğitime bağlı bir okul olan Gazimağusa Özel Eğitim Merkezi'nden eğitim almaktadırlar. Bazı çocuklar tam gün eğitim almakta, bazı çocuklar ise seanslı eğitim (Haftada 4-5 saat) almaktadırlar. Okul ve öğretmen yetersizliği sorun alanından bahsedildiğinde, bazıları haftalık aldığı seans sayısının azlığından yakınmışlar, bazıları ise yaz döneminde çocukların tamamen okulsuz kalmasını bir eksiklik olarak gördüklerini belirtmişlerdir.

A5, okullara kabul ile yaşadığı sorunu "Çocuğumu ilk kreşe götürdüğümde birçok kreş kabul etmedi. Kreş sahipleri istemedi, olmaz, diğer aileler kabul etmez dedi. Bizi tersler gibi oldu. Ben oradan gözyaşı ile ayrıldım. Öğretmenlik bunu mu gerektirir, diye sordum" şeklinde ifade etti. A13, çocuğunun durumu ile sağlıklı bilgi alamamasına örnek olarak şöyle ifade etti: "Götürdüğümüz ilk doktor; 'hiç doktor doktor gezme, bu çocuktan ne köy ne kasaba olur, çiftçi olur sadece 'dedi."

\subsection{Annelerin Yaşadığı Ekonomik Güçlükler}

Tablo 3.6. Annelerin Yaşadığı Ekonomik Güçlükler

\begin{tabular}{llll}
\hline S.N. & Ekonomik Güçlükler & f & \% \\
\hline $\mathbf{1}$ & Sağlık harcamaları & 8 & 53 \\
$\mathbf{2}$ & Bez, bakım, giysi masrafları & 6 & 40 \\
$\mathbf{3}$ & Ek destek eğitim harcamaları & 5 & 33 \\
$\mathbf{4}$ & Türkiye'den alınan hizmetlerin- yol, & 5 & 33 \\
& sağlık, ikamet etme- masrafları & & \\
$\mathbf{5}$ & Yol ve ulaşım masrafları & 4 & 27 \\
$\mathbf{6}$ & Maaş bağlanmaması & 2 & 13 \\
$\mathbf{7}$ & Çocuktan dolayı çalışamama & 2 & 13 \\
\hline
\end{tabular}

Araştırmaya katılan 12 anne, ekonomik güçlükler yaşadıklarını belirtmişlerdir. Demografik verilerin alındığı kişisel bilgi formunda 7 anne maddi durumu için düşük ifadesini kullanmış, 7 anne orta seçeneğini işaretlemiştir. Ekonomik sorun yaratan faktörlerin başında sağlık masrafları gelmektedir. Burada bahsettikleri sağlık masrafları; çocuğun ilk tanısının alınması aşamasında gerekli doktor masrafları, tanı ve tanı için Türkiye'ye gitmede kullanılan yol masrafları, ilaç masrafları, bez masrafları ve ameliyat masraflarıdır. Özellikle çoklu yetersizliğe sahip ve beraberinde başka bir hastalığı olan çocukların tedavisi sağlık harcamaları yaratmaktadır. A11; iki buçuk sene boyunca her ay Türkiye'ye gelip gittiklerini belirtmiştir. A5; tedavisi için gerekli olan ameliyatı Türkiye'de olmuştur. A10, çocuğunun tedavisi için 2 y1l Türkiye'de yakınlarının yanında kaldığını belirtmiştir.

İkinci olarak şikayet edilen konu çocukların bazılarının tuvalet kontrolü olmadığı için bezlenmeleri dolayısıyla oluşan bez masrafidır. Anneler bez kullanmanın masraflı olduğunu ifade etmiş, bu konuda düzenli yardım almadıklarını bildirmişlerdir. Anneler bir diğer sorun olarak, çocuklarının özel eğitim seanslarının masrafını da önemli bir harcama olarak belirtmişler, seanslarına 50-100 TL arası ödediklerini, haftada 2 veya $3 \mathrm{kez}$ gittiklerini hem bu masrafın hem de eğitim kurumuna ulaşım için yaptıkları yol masrafının önemini vurgulamışlardır. Annelerin birçoğu geçmişte çocuklarına ücretli özel eğitim veya fizyoterapi desteği aldırmışlardır. Kişisel bilgi formlarından elde edilen veriye göre görüşmelerin yapıldığı sırada 6 anne çocuğu için ek destek eğitim aldırmaya devam etmektedir.

Anneler; ekonomik sorunlarını aşağıda verilen alıntılarda olduğu gibi ifade etmişlerdir. A11; "En çok para Türkiye'ye yaptığımız yolculuklara gitti. Oradaki ameliyatlar sırasında orada kalışlarımız hepsine çok para gitti." A13; "Çok özel eğitim seanslarına götürdüm, bir fayda göremedim, unutuyordu. Bir saatle öğrenmiyor en az bir ay tekrar etmek gerekiyor." A4; "Doğar doğmaz aslında maaşa bağlanabilirdi, ama ben kabullenemedim, çocuğumu engelli olarak görmedim, ben bu çocuğa bakamayacak miyım? dedim ve o engelli maaşına başvurmadım. Daha sonra düşündüm ki bu çocuğun hakkıdır, o parayla kendi ihtiyaçlarını karşılayabilirim.” Eğitim masrafları yaptığını ancak bunun ekonomik bir sorun yaratmadığını belirten A3, görüşlerini şöyle ifade etmiştir;" Herkes zaten birtakım kurslara gönderiyor, ben de özel eğitim aldırdım, o yüzden bir fark yaşamadım".

\subsection{Annelerin Yaşadıkları Güçlükler Karşısında Uyguladıkları Başa Çıkma Yöntemleri}

Genel sonuçlara göre annelerin en çok kullandığ başa çıkma yöntemi; problem odaklı başa çıkma yöntemidir. Duygu odaklı başa çıkma yöntemleri ikinci sırada kullanılmış, işlevsel olmayan başa çıkma yöntemleri ise en az kullanılan yöntem olmuştur. Aşağıda annelerin kullandıkları başa çıkma yöntemlerinin frekans analizi ile elde edilmiş oranları görülmektedir.

Tablo 3.7. Annelerin Kullandığı Başa Çıkma Yöntemleri

\begin{tabular}{lllll}
\hline Anneler & P.O. \% & D.O. \% & I.O. \% & $\begin{array}{l}\text { Annenin } \\
\text { ağırlıklı } \\
\text { olarak } \\
\text { kullandı̆̆ı } \\
\text { başa çıkma } \\
\text { yöntemi }\end{array}$ \\
& & & & \\
& & & & \multicolumn{1}{c}{} \\
\hline A1 & 58 & 42 & 0 & P.O. \\
A2 & 33 & 50 & 17 & D.O. \\
A3 & 11 & 44 & 44 & D.O.-İ.O. \\
A4 & 56 & 17 & 28 & P.O. \\
A5 & 47 & 26 & 26 & P.O. \\
A6 & 36 & 55 & 9 & D.O. \\
A7 & 76 & 24 & 0 & P.O. \\
A8 & 21 & 36 & 43 & I.O. \\
A9 & 33 & 42 & 25 & D.O. \\
A10 & 53 & 21 & 26 & P.O. \\
A11 & 62 & 29 & 10 & P.O. \\
A12 & 47 & 33 & 20 & P.O. \\
A13 & 50 & 50 & 0 & P.O.-D.O. \\
A14 & 28 & 44 & 28 & D.O. \\
A15 & 42 & 33 & 25 & P.O. \\
\hline
\end{tabular}

$\mathrm{Bu}$ tabloda her bir annenin tüm başa çıkma yanıtları incelenerek, kullandığı başa çıkma yöntemlerinin daha çok hangi alanda toplandığı yüzdelik oranı olarak incelenmiştir. $\mathrm{Bu}$ sonuçlara göre araştırmaya katılan annelerin çoğu, zihinsel yetersizliğe sahip bir çocuğu olmakla ilgili sorunlarının çözümünde problem odaklı başa çıkma yöntemleri kullanmaktadır. Aşağıdaki tabloda ise kullanılan başa çıkma yöntemlerinin frekansları ve oranları incelenmiştir. 
Tablo 3.8. Başa Çıkma Yöntemleri Genel Sonuçları

\begin{tabular}{|c|c|c|c|c|c|}
\hline & $\begin{array}{l}\text { Temel } \\
\text { Başa } \\
\text { Çıkma } \\
\text { Alanları }\end{array}$ & $\begin{array}{l}\text { Başa Çıkma Alt } \\
\text { Alanları }\end{array}$ & $\begin{array}{l}\text { Kullan } \\
\text { ma } \\
\text { sayısı } \\
\text { (f) }\end{array}$ & $\%$ & $\begin{array}{l}\text { Temel } \\
\text { Alan } \\
\text { Sonuçl } \\
\text { arı \% }\end{array}$ \\
\hline \multirow[t]{5}{*}{1} & Problem & Aktif başa çıkma & 33 & 15 & 45 \\
\hline & Odaklı & Plan yapma & 10 & 5 & \\
\hline & $\begin{array}{l}\text { Başa } \\
\text { Çıkma }\end{array}$ & $\begin{array}{l}\text { Yararlı sosyal } \\
\text { destek kullanımı }\end{array}$ & 27 & 12 & \\
\hline & & $\begin{array}{l}\text { Diğer } \\
\text { meşguliyetleri } \\
\text { bastırma }\end{array}$ & 16 & 7 & \\
\hline & & Geri durma & 12 & 6 & \\
\hline \multirow[t]{5}{*}{2} & $\begin{array}{l}\text { Duygu } \\
\text { Odaklı }\end{array}$ & $\begin{array}{l}\text { Duygusal destek } \\
\text { kullanımı }\end{array}$ & 21 & 10 & 35 \\
\hline & $\begin{array}{l}\text { Başa } \\
\text { Çıma }\end{array}$ & $\begin{array}{l}\text { Dini olarak başa } \\
\text { çıkma }\end{array}$ & 15 & 7 & \\
\hline & & $\begin{array}{l}\text { Pozitif yeniden } \\
\text { yorumlama ve } \\
\text { gelişme }\end{array}$ & 10 & 5 & \\
\hline & & Kabullenme & 28 & 13 & \\
\hline & & $\begin{array}{l}\text { Şaka ve mizah } \\
\text { kullanımı }\end{array}$ & 2 & 1 & \\
\hline \multirow[t]{5}{*}{3} & $\begin{array}{l}\text { İşlevsel } \\
\text { Olmayan } \\
\text { Başa } \\
\text { Çıkma }\end{array}$ & $\begin{array}{l}\text { Soruna } \\
\text { odaklanma, } \\
\text { duyguları açığa } \\
\text { vurma }\end{array}$ & 9 & 4 & 20 \\
\hline & & İnkar & 7 & 3 & \\
\hline & & $\begin{array}{l}\text { Zihinsel boş } \\
\text { verme }\end{array}$ & 13 & 6 & \\
\hline & & $\begin{array}{l}\text { Davranışsal boş } \\
\text { verme }\end{array}$ & 15 & 7 & \\
\hline & & Madde kullanımı & 0 & 0 & \\
\hline
\end{tabular}

3.7. Annelerin Psikolojik Sorunlarla Başa Çıkma Yöntemleri

Tablo 3.9. Annelerin Psikolojik Sorunlarla Başa Çıkma Yöntemleri

\begin{tabular}{|c|c|c|c|c|c|}
\hline & $\begin{array}{l}\text { Temel } \\
\text { Başa } \\
\text { Çıkma } \\
\text { Alanları }\end{array}$ & $\begin{array}{l}\text { Başa Çıkma Alt } \\
\text { Alanları }\end{array}$ & $\begin{array}{l}\text { Alt } \\
\text { Sonuç } \\
\text { lar }\end{array}$ & $\begin{array}{l}\text { Temel } \\
\text { Alan } \\
\text { Sonuç } \\
\text { ları }\end{array}$ & $\%$ \\
\hline \multirow[t]{6}{*}{1} & Problem & Aktif başa çıkma & 6 & 19 & 28 \\
\hline & Odaklı & Plan yapma & 3 & & \\
\hline & Başa & Yararlı sosyal destek & 4 & & \\
\hline & Çıkma & kullanımı & & & \\
\hline & & $\begin{array}{l}\text { Diğer meşguliyetleri } \\
\text { bastırma }\end{array}$ & 2 & & \\
\hline & & Geri durma & 4 & & \\
\hline \multirow[t]{5}{*}{2} & $\begin{array}{l}\text { Duygu } \\
\text { Odakl }\end{array}$ & $\begin{array}{l}\text { Duygusal destek } \\
\text { kullanım1 }\end{array}$ & 10 & 34 & 51 \\
\hline & $\begin{array}{l}\text { Başa } \\
\text { Çıkma }\end{array}$ & $\begin{array}{l}\text { Dini olarak başa } \\
\text { çıkma }\end{array}$ & 7 & & \\
\hline & & $\begin{array}{l}\text { Pozitif yeniden } \\
\text { yorumlama ve gelişme }\end{array}$ & 6 & & \\
\hline & & Kabullenme & 11 & & \\
\hline & & $\begin{array}{l}\text { Şaka ve mizah } \\
\text { kullanımı }\end{array}$ & 0 & & \\
\hline \multirow[t]{5}{*}{3} & $\begin{array}{l}\text { İşlevsel } \\
\text { Olmayan }\end{array}$ & $\begin{array}{l}\text { Soruna odaklanma, } \\
\text { duyguları açığa vurma }\end{array}$ & 4 & 14 & 21 \\
\hline & Bașa & İnkar & 4 & & \\
\hline & Cıkma & Zihinsel bos verme & 2 & & \\
\hline & & Davranıșsal boș verme & 4 & & \\
\hline & & Madde kullanımı & 0 & & \\
\hline
\end{tabular}

Anneler, psikolojik sorun alanlarında daha çok duygu odaklı başa çıkma yöntemlerini kullanmışlardır. Bunlar arasında ise kabullenme ve duygusal destek kullanımı en sık başvurdukları başa çıkma yöntemi olmuştur.

yöntemi olmuştur. Duygu odaklı yöntemler \%35 oranında kullanılmış, en az ise işlevsel olmayan yöntemler kullanılmıştır. En çok kullanılan başa çıkma yöntemleri aktif başa çıkma, kabullenme, yararlı sosyal destek kullanımı, duygusal destek kullanımıdır. Bunlardan aktif başa çıkma ve yararlı sosyal destek kullanımı problem odaklı yöntemler olup; kabullenme ve duygusal destek kullanımı ise duygu odaklı başa çıkma yöntemleri arasındadır.

$\mathrm{Bu}$ sonuçların yanı sıra annelerin başa çıkma yöntemlerinin sorun alanlarına göre değiştiği görülmüştür. Anneler, örneğin, psikolojik alandaki sorunlarını çözmede farklı, eğitim alanındaki sorunlarını çözmede farklı başa çıkma alanındaki becerilerini kullanmışlardır. Sonuçlar aşağıda ayrıntılarıyla anlatılmıştır.
A6" Artık bizim için hayat daha farklı, çocuğumuza ne verebiliriz, onun üstünde durduk. Üzüldük ama kendimizi parçalamadık. Parçalasak ne yapabileceğiz, olan çocuğa olacak." Şeklinde kabullenme sürecini anlatmıştır. A7; "Eşim çok özverili bir baba, 'yere basma, bağrıma bas' diyecek birisi, baba gibi bir baba, bana da çok destek oldu, çok şefkatli, anlayışlı ve hoşgörülü, sevgisi sınırsız. Eşlerin birbirine destek olması çok önemli. O bana hep 'üzülme, iyi olacak, üzülme, rabbimden ne geldiyse odur, ona dua edelim, elimizden ne gelirse onu yapacağız, ağlamak bir çözüm değil' dedi, psikiyatrist doktorum gibiydi eşim" diyerek eşinden aldığı duygusal desteği ifade etmiştir. A13;" Ablam bir nevi psikoloğum oldu. Kendine gel, önce çocuğunu düşün, biz her zaman arkanda olacağız, böyle ilk anne değilsin, son anne de olmayacaksın dedi. Bu çocuk hepimizin, hepimiz sana ve ona destek olacağız dedi. Beni motive etti" diyerek duygusal destek kullanımına işaret etmiştir. A7; eşinden ve diğer çocuklarından aldığı desteği, "çocuklarım, kardeşleri için canlarını verecek durumdalar, anne babayı örnek alıyorlar bence. Bu beni çok etkiliyor. Oğlumun psikolojisi bozulmasın diye herkes seferber evde" diyerek belirtmiştir. 


\subsection{Annelerin Eş Ve Diğer Çocuklariyla Olan Sorunlarinda Başa Çikma Yöntemleri}

Tablo 3.10. Annelerin Eş ve Diğer Çocuklarıyla Olan Sorunlarında Başa Çıkma Yöntemleri

\begin{tabular}{|c|c|c|c|c|c|}
\hline & $\begin{array}{l}\text { Temel } \\
\text { Başa } \\
\text { Çıkma } \\
\text { Alanları }\end{array}$ & $\begin{array}{l}\text { Başa Çıkma Alt } \\
\text { Alanları }\end{array}$ & $\begin{array}{l}\text { Alt } \\
\text { Sonuçl } \\
\text { ar }\end{array}$ & $\begin{array}{l}\text { Teme } \\
\text { l } \\
\text { Alan } \\
\text { Sonu } \\
\text { çları }\end{array}$ & $\%$ \\
\hline \multirow[t]{5}{*}{1} & Problem & Aktif başa çıkma & 4 & 12 & 33 \\
\hline & Odaklı & Plan yapma & 1 & & \\
\hline & Başa & Yararli sosyal & 5 & & \\
\hline & & $\begin{array}{l}\text { Diğer } \\
\text { meşguliyetleri } \\
\text { bastırma }\end{array}$ & 1 & & \\
\hline & & Geri durma & 1 & & \\
\hline \multirow[t]{5}{*}{2} & Duygu & $\begin{array}{l}\text { Duygusal destek } \\
\text { kullanımı }\end{array}$ & 4 & 16 & 44 \\
\hline & $\begin{array}{l}\text { Başa } \\
\text { Çıkma }\end{array}$ & $\begin{array}{l}\text { Dini olarak başa } \\
\text { çıkma }\end{array}$ & 1 & & \\
\hline & & $\begin{array}{l}\text { Pozitif yeniden } \\
\text { yorumlama ve } \\
\text { gelişme }\end{array}$ & 2 & & \\
\hline & & Kabullenme & 8 & & \\
\hline & & $\begin{array}{l}\text { Şaka ve mizah } \\
\text { kullanımı }\end{array}$ & 1 & & \\
\hline \multirow[t]{5}{*}{3} & $\begin{array}{l}\text { İşlevsel } \\
\text { Olmayan } \\
\text { Başa } \\
\text { Çıkma }\end{array}$ & $\begin{array}{l}\text { Soruna } \\
\text { odaklanma, } \\
\text { duyguları açığa } \\
\text { vurma }\end{array}$ & 1 & 8 & 22 \\
\hline & & İnkar & 0 & & \\
\hline & & $\begin{array}{l}\text { Zihinsel boş } \\
\text { verme }\end{array}$ & 3 & & \\
\hline & & $\begin{array}{l}\text { Davranışsal boş } \\
\text { verme }\end{array}$ & 4 & & \\
\hline & & Madde kullanımı & 0 & & \\
\hline
\end{tabular}

Eş ve diğer çocuklarla olan iletişim sorunlarında da yine duygu odaklı başa çıkma yöntemleri daha fazla kullanılmıştır. Bunlardan en çok kullanılan ise kabullenme olmuştur. Anneler aile içindeki sorunlarıyla baş ederken kabullenmenin yanı sıra yararlı sosyal destek kullanımı, duygusal destek kullanımı, davranışsal boş verme yöntemlerini de kullanmışlardır.

A11, eşi ile ilgili kabulünü "Eşimi biraz da biz tedavi süreçlerinden soyutladık, çünkü biraz aksi biridir, doktorla öğretmenle tartışıp bir tatsızlık oluşsun istemedik" diyerek belirtmiştir. A2, çocuğu daha küçükken özel eğitimini aksattığını bunu da doğru bulmadığını şu sözlerle ifade etmiştir. "Babası yapmıyor diye yapmazlık etmemek lazım, o zaten yapar diye ben de araştırmadım, şimdi olsa farklı yapardım" Aynı anne yine davranışsal boş verme ile ilgili "baba yapmiyor, ben niye yapayım, o baksın, o götürsün dememek lazım, ne gerekiyorsa yapmak lazım, baktın yapmıyor, boş ver deyip kendin çocuğun ihtiyaçlarını göreceksin" şeklinde kabullenme yönteminin kullanımına işaret etmiştir.

3.9. Annelerin Yakın Çevre (Geniş Aile, Akrabalar, Komşular, Tanıdıklar) ile Olan Sorunlarıyla Başa Çıkma Yöntemleri

Tablo 3.11. Annelerin çevre (yakın, arkadaş, akraba) ile olan sorunlarıyla başa çıkma yöntemleri

\begin{tabular}{|c|c|c|c|c|c|}
\hline & $\begin{array}{l}\text { Temel } \\
\text { Başa } \\
\text { Çıkma } \\
\text { Alanları }\end{array}$ & $\begin{array}{l}\text { Başa Çıkma } \\
\text { Alt Alanları }\end{array}$ & $\begin{array}{l}\text { Alt } \\
\text { Sonuçlar }\end{array}$ & $\begin{array}{l}\text { Temel } \\
\text { Alan } \\
\text { Sonuçları }\end{array}$ & $\%$ \\
\hline \multirow[t]{5}{*}{1} & $\begin{array}{l}\text { Problem } \\
\text { Odakl1 }\end{array}$ & $\begin{array}{l}\text { Aktif başa } \\
\text { cıkma }\end{array}$ & 5 & 18 & 37 \\
\hline & Basa & Plan yapma & 2 & & \\
\hline & Çıkma & $\begin{array}{l}\text { Yararlı sosyal } \\
\text { destek } \\
\text { kullanımı }\end{array}$ & 6 & & \\
\hline & & $\begin{array}{l}\text { Diğer } \\
\text { meşguliyetleri } \\
\text { bastırma }\end{array}$ & 3 & & \\
\hline & & Geri durma & 2 & & \\
\hline \multirow[t]{7}{*}{2} & Duygu & Duygusal & 5 & 20 & 41 \\
\hline & Odaklı & destek & & & \\
\hline & Başa & kullanımı & & & \\
\hline & Çıkma & $\begin{array}{l}\text { Dini olarak } \\
\text { bașa çıkma }\end{array}$ & 6 & & \\
\hline & & $\begin{array}{l}\text { Pozitif yeniden } \\
\text { yorumlama ve } \\
\text { gelişme }\end{array}$ & 1 & & \\
\hline & & Kabullenme & 7 & & \\
\hline & & $\begin{array}{l}\text { Şaka ve mizah } \\
\text { kullanımı }\end{array}$ & 1 & & \\
\hline \multirow[t]{7}{*}{3} & İşlevsel & Soruna & 1 & 11 & 22 \\
\hline & $\begin{array}{l}\text { Olmayan } \\
\text { Basa }\end{array}$ & odaklanma, & & & \\
\hline & & açığa vurma & & & \\
\hline & & İnkar & 0 & & \\
\hline & & $\begin{array}{l}\text { Zihinsel boş } \\
\text { verme }\end{array}$ & 6 & & \\
\hline & & $\begin{array}{l}\text { Davranışsal } \\
\text { boş verme }\end{array}$ & 4 & & \\
\hline & & $\begin{array}{l}\text { Madde } \\
\text { kullanımı }\end{array}$ & 0 & & \\
\hline
\end{tabular}

Annelerin en az sorun belirttiği alan olan yakın çevre ile olan sorunlarda daha çok duygu odaklı başa çıkma yöntemleri kullanılmıştır. Alt alanlara bakıldığında en çok kullanılan yöntemlerin kabullenme, dini olarak başa çıkma, yararlı sosyal destek kullanımı ve zihinsel boş verme olduğu görülmüştür. Bunlardan ilk ikisi duygusal bir başa çıkma yöntemi iken yararlı sosyal destek kullanımı; problem odakl1, zihinsel boş verme ise işlevsel olmayan bir başa çıkma yöntemine işaret etmektedir.

A13; çevrenin anlayışsızlığg sorunu ile ilgili bir sıkıntısı hakkında şunu söylemiştir. "Benim kızımı okulda istemiyordu, 'torunum senin kızından korkuyor 'diyordu, öğretmene şikayet ediyordu, şimdi ne oldu, onun da diğer torunu konuşma terapisi alıyor, ben işimi Allaha bırakırım." Şeklinde konuşarak kendisini duygusal olarak rahatlatmak için dini başa çıkma yöntemini kullandığını ifade etmek istemiştir. A12; kaynanası ile yaşadığı sorunları geri durma, dini başa çıkma ve yararlı sosyal destek kullanımı yöntemi ile aştığını şu sözlerle ifade etmiştir; "Önceden kaynanamla yan yanaydı evlerimiz, bana çok eziyet ediyordu, sen sağlıklı 
çocuk doğuramadın, sen de doğursaydın sana da araba alırdım, demişti bir keresinde. Diğer eltilerime aldı, ama onlar da binemediler, biri kaza yaptı, biri sattı, almasın. Çok bunalmıştım ondan, herkesin içinde çocuğuma hakaretler ediyordu. Bir sene önce kardeşlerimin de desteği ile oradan taşındım, şimdi artık onu görmüyorum, eşim de görüşmüyor annesiyle, şu an çok rahatım, şükür”.

3.10. Annelerin Eğitimle İlgili Sorunlarla Başa Çıkma Yöntemleri

Tablo 3.12. Annelerin Eğitimle İlgili Sorunlarla Başa Çıkma Yöntemleri

\begin{tabular}{|c|c|c|c|c|c|}
\hline & $\begin{array}{l}\text { Temel } \\
\text { Başa } \\
\text { Çıkma } \\
\text { Alanları }\end{array}$ & $\begin{array}{l}\text { Başa Çıkma } \\
\text { Alt Alanları }\end{array}$ & $\begin{array}{l}\text { Alt } \\
\text { Sonuçlar }\end{array}$ & $\begin{array}{l}\text { Temel } \\
\text { Alan } \\
\text { Sonuçları }\end{array}$ & $\%$ \\
\hline \multirow[t]{5}{*}{1} & $\begin{array}{l}\text { Problem } \\
\text { Odakl1 }\end{array}$ & $\begin{array}{l}\text { Aktif başa } \\
\text { çıma }\end{array}$ & 12 & 32 & 71 \\
\hline & Başa & Plan yapma & 4 & & \\
\hline & Çıkma & $\begin{array}{l}\text { Yararlı sosyal } \\
\text { destek } \\
\text { kullanımı }\end{array}$ & 6 & & \\
\hline & & $\begin{array}{l}\text { Diğer } \\
\text { meşguliyetleri } \\
\text { bastırma }\end{array}$ & 5 & & \\
\hline & & Geri durma & 5 & & \\
\hline \multirow[t]{5}{*}{2} & $\begin{array}{l}\text { Duygu } \\
\text { Odaklı } \\
\text { Basa }\end{array}$ & $\begin{array}{l}\text { Duygusal } \\
\text { destek } \\
\text { kullanımı }\end{array}$ & 2 & 5 & 11 \\
\hline & Çıkma & $\begin{array}{l}\text { Dini olarak } \\
\text { başa çıkma }\end{array}$ & 1 & & \\
\hline & & $\begin{array}{l}\text { Pozitif } \\
\text { yeniden } \\
\text { yorumlama ve } \\
\text { gelişme }\end{array}$ & 0 & & \\
\hline & & Kabullenme & 2 & & \\
\hline & & $\begin{array}{l}\text { Şaka ve mizah } \\
\text { kullanımı }\end{array}$ & 0 & & \\
\hline \multirow[t]{5}{*}{3} & $\begin{array}{l}\text { İşlevsel } \\
\text { Olmayan } \\
\text { Başa }\end{array}$ & $\begin{array}{l}\text { Soruna } \\
\text { odaklanma, } \\
\text { duyguları }\end{array}$ & 3 & 8 & 18 \\
\hline & Çıkma & $\begin{array}{l}\text { açığa vurma } \\
\text { İnkar }\end{array}$ & 2 & & \\
\hline & & $\begin{array}{l}\text { Zihinsel boş } \\
\text { verme }\end{array}$ & 1 & & \\
\hline & & $\begin{array}{l}\text { Davranışsal } \\
\text { boş verme }\end{array}$ & 2 & & \\
\hline & & $\begin{array}{l}\text { Madde } \\
\text { kullanımı }\end{array}$ & 0 & & \\
\hline
\end{tabular}

Tüm annelerin sorun yaşadığını belirttiği eğitimle ilgili sorunlarda, belirgin bir farkla problem odaklı yöntemler kullanılmıştır. $\mathrm{Bu}$ yöntemler arasında en çok aktif başa çıkma, yararlı sosyal destek kullanımı, diğer meşguliyetleri bastırma ve geri durmanın kullanıldı $\breve{1}$ belirtilmiştir.

A7 eğitimle ilgili aktif başa çıkma çabalarını "İlkokul müdürü okula kabul etmek istemedi. Gölge öğretmen olsun dedi, onu da tuttum. Bu sefer onu beğenmedi, olmaz dedi. O bir ay çok zorlandım. Üç kere bakanlığa gittim, eşimle de gittim. Yazım çıksın diye (Eğitsel Yöneltme Raporu). Başlarda rapor da yetmedi ama sonunda kabul etti." şeklinde ifade etmiştir. A9 ve A2 ders saatlerinin azlığından şikayet etmiş, bu konuyla ilgili olarak okul müdürü ile görüştüklerini söylemişlerdir. A2 annelerin bakanlığa gidip görüşme yaptıklarını, kendisinin de bir dahaki sefere katılacağını belirtmiş, ayrıca çocuğun eğitim saatlerini yetersiz bulduğu için dışardan destek eğitim verecek kişi arayışı içinde olduğunu ifade etmiştir. $\mathrm{Bu}$; annelerin aktif başa çıkma yöntemleri kullanmasına bir örnektir. A7; "Özel eğitim merkezinden birisi bana yol gösterdi. Türkiye'de bir yer tavsiye etti. Orada çok olanakları olan bir okula gittim" diyerek, A10; "Bir gün parkta oynarken tanımadığım birisi yanıma geldi ve Mağusa'daki özel eğitim okulundan bahsetti. Oraya git dedi. Öylece haberim oldu. Okula gidince beni aldılar. Böylece eğitime başladı" diyerek yararlı sosyal destek kullanımına örnek vermişlerdir.

3.11. Annelerin Ekonomik Sorunlarla Başa Çıkma Yöntemleri

Tablo 3.13. Annelerin Ekonomik Sorunlarla Başa Çıkma Yöntemleri

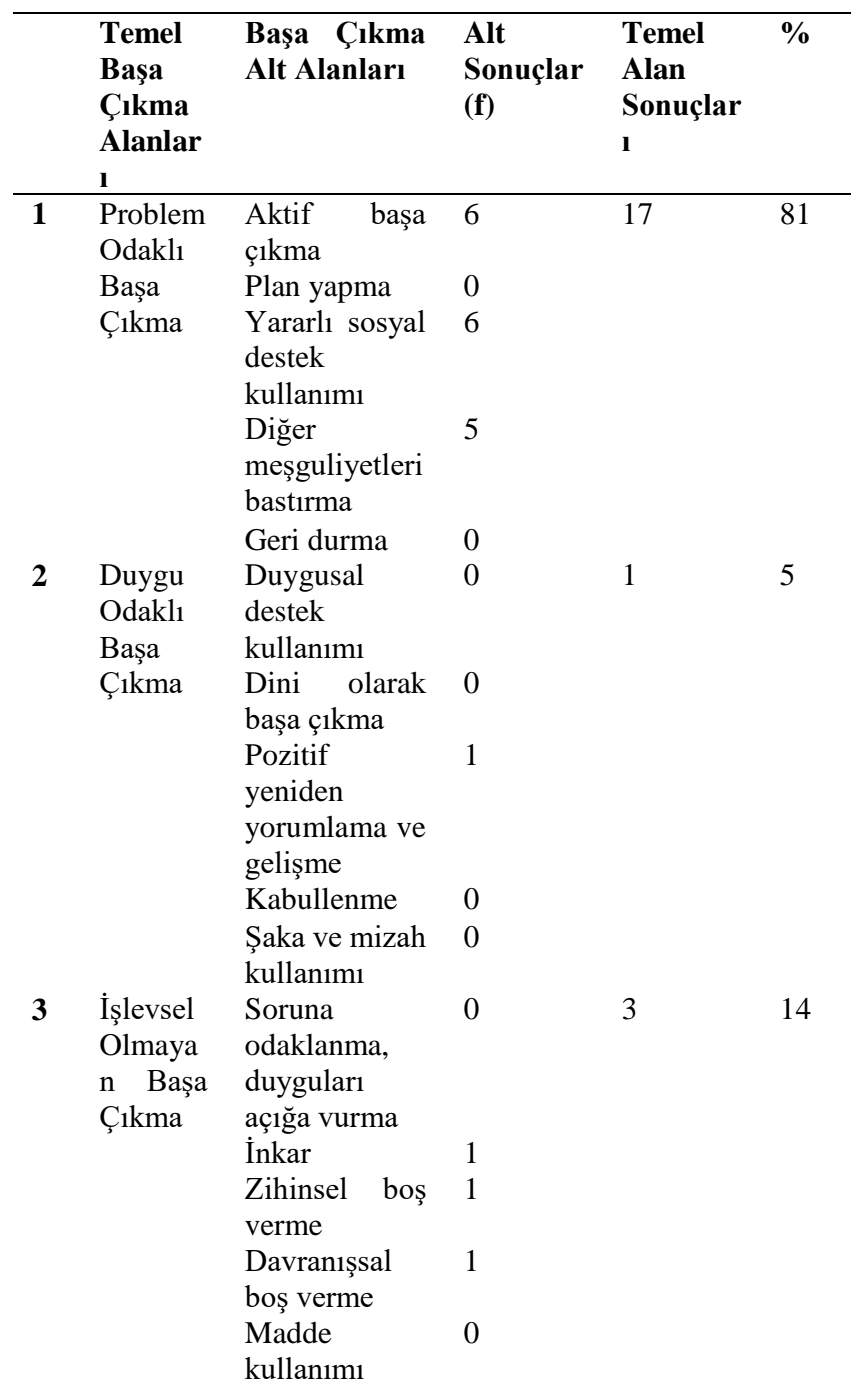

Ekonomik sorun yaşadığını belirten 12 anne en çok problem odaklı yöntemlerle sorunlarını çözmeye çalışmışlar ve aktif başa çıkma, yararlı sosyal destek kullanımı ve diğer meşguliyetleri bastırma yöntemlerini kullanmışlardır.

A11," Bizim için öncelikler, beslenme, sağlık ve tedavi harcamalarıdır. Onun dışında eğlenceymiş, giyinmek, eşya, hep geri planda. Olmasın. Dışarda da eğlenmeyi ver" diyerek diğer meşguliyetlerini bastırdığını dile getirmiştir. A1; "Marketimizi kapatmak zorunda kaldık, oluşan borçlarımızı 
babam ödedi, toparladık" demiș ve yararlı sosyal destek kullanımını işaret etmiştir.

\subsection{Annelerin Kullandıkları Başa Çıkma Yöntemlerinin Etkililiği}

Aşağıda tüm sorun alanlarında kullanılan problem odaklı, duygu odaklı ve işlevsel olmayan başa çıkma yöntemlerinin sorun alanlarına göre yüzdelik oranları verilmiştir. Son sütunda ise araştırmaya konu olan sorun alanlarının tümünde kullanılan başa çıkma yöntemlerinin oranları verilmiştir.

Tablo 3.14. Başa Çıkma Yöntemlerinin Sorun Alanlarına Göre Oransal İncelenmesi

\begin{tabular}{|c|c|c|c|c|c|c|}
\hline $\begin{array}{l}\text { Başa } \\
\text { Çıkma } \\
\text { Yöntemleri }\end{array}$ & $\begin{array}{l}\text { Psi } \\
\text { kol } \\
\text { oji } \\
\mathbf{k} \\
\text { güç } \\
\text { lük } \\
\text { ler }\end{array}$ & $\begin{array}{l}\text { Eş ve } \\
\text { diğer } \\
\text { çocukl } \\
\text { arla } \\
\text { yaşana } \\
\text { n } \\
\text { güçlük } \\
\text { ler }\end{array}$ & $\begin{array}{l}\text { Yakın } \\
\text { çevre } \\
\text { ile } \\
\text { yaşana } \\
\text { n } \\
\text { güçlük } \\
\text { ler }\end{array}$ & $\begin{array}{l}\text { Ĕgiti } \\
\text { mle } \\
\text { ilgili } \\
\text { güçl } \\
\text { ükle } \\
\text { r }\end{array}$ & $\begin{array}{l}\text { Eko } \\
\text { nomi } \\
\mathbf{k} \\
\text { güçl } \\
\text { ükle } \\
\mathbf{r}\end{array}$ & $\begin{array}{l}\text { Tüm } \\
\text { güçlü } \\
\text { kler }\end{array}$ \\
\hline $\begin{array}{l}\text { Problem } \\
\text { Odaklı }\end{array}$ & $\begin{array}{l}\% 2 \\
8\end{array}$ & $\% 33$ & $\% 37$ & $\% 71$ & $\begin{array}{l}\% 8 \\
1\end{array}$ & $\% 50$ \\
\hline $\begin{array}{l}\text { Duygu } \\
\text { Odaklı }\end{array}$ & $\begin{array}{l}\% 5 \\
1\end{array}$ & $\% 44$ & $\% 41$ & $\% 11$ & $\% 5$ & $\% 30,4$ \\
\hline $\begin{array}{l}\text { İşlevsel } \\
\text { Olmayan }\end{array}$ & $\begin{array}{l}\% 2 \\
1\end{array}$ & $\% 22$ & $\% 22$ & $\% 18$ & $\% 14$ & $\% 19,4$ \\
\hline
\end{tabular}

Tabloya göre problem odaklı yöntemler en çok ekonomik sorunların çözümünde kullanılmış, en az ise psikolojik ve eş ve diğer çocuklarla yaşanan sorunlarda kullanılmıştır. Duygu odaklı yöntemler en çok psikolojik sorunlarla başa çıkarken kullanılmış, en az ekonomik sorunlarda kullanılmıştır. İşlevsel olmayan yöntemlerin en fazla kullanıldığı sorun alanı eş ve diğer çocuklarla yaşanan güçlükler olmuş, en az kullanıldığı alan ise ekonomik güçlükler olmuştur.

Derinlemesine yapılan görüșmeler sonucu elde edilen sonuçlara göre anneler en sıklıkla ve bireysel sonuçlarına göre en ağırlıklı olarak problem odaklı başa çıkma yöntemini kullanmaktadırlar. Problem odaklı yöntemler hem yöntem olarak en çok kullanılanlar yöntemler olmuş hem de annelerin çoğu ( 8 tanesi) ağırlıklı olarak problem odaklı başa çıkma yöntemleri kullanmışlardır. Sonuçlar işlevsel ve işlevsel olmayan yöntemler olarak değerlendirildiğinde; annelerin \%90'1 ağırlıklı olarak işlevsel yöntemler kullanmışlardır (\%57 problem odaklı, \%33 duygu odaklı başa çıkma kullananlar toplamı, tablo 3.7.) \%10 oranında anne genel olarak işlevsel olmayan yöntemler kullanmıştır.

Kişisel bilgi formundan elde edilen veriler ile yaşanan güçlükler yan yana getirildiğinde şu sonuçlar çıkmıştır. Yaşı 36-40 arasında olan anneler daha fazla sorun belirtmişlerdir. "Genel olarak kendinizi nasıl hissediyorsunuz?" sorusuna zor durumda şeklinde yanıt verenler daha yüksek oranda sorun belirtmişlerdir. Zihinsel yetersizliği olan çocuğu, 0-6 yaş arasında olan anneler diğerlerinden daha fazla sorun belirtmişlerdir. Çoklu yetersizliğe sahip çocuğu olan anneler, çocuğun tanı alma yaşı 0-3 yaşında olanlar, zihinsel yetersizlik nedeni olarak doğum sirası ve doğum sonrası olarak belirtenler (doğum öncesi ve belirsiz seçeneğine kıyasla), çocuğunun bakımında aile üyelerinden az destek alanlar daha fazla alanda sorun belirtmişlerdir. Annenin gelir durumu, ailede başka yetersizliği olan bireyin olması durumu, alınan psikolojik yardım, çocuğun okuma yazma bilip bilmemesi, eğitim alınan süre, yetersizliği olan çocuğun yaşı gibi değişkenlere göre yaşanan sorunların sayısında bir değişiklik görülmemiştir. Çocuğun bakım ve eğitiminde aile üyelerinden "az" destek aldıklarını belirten 5 anneden 4'ü aile ve kardeşle yaşanan sorunlardan bahsetmişlerdir. Başa çıkma yöntemleri aynı değişkenlerle kıyaslandığında ise şu sonuçlar elde edilmiştir. İşlevsel olmayan başa çıkma yöntemini ağırlıklı olarak kullanan 2 anne de evde başka bir yetersizliğe sahip bireyin olduğunu belirtmiştir.

Problem odaklı başa çıkma yöntemlerinden en fazla kullanılanları aktif başa çıkma ve yararlı sosyal destek kullanımıdır. Duygu odaklı başa çıkma alt alanlarından ise en fazla kabullenme ve duygusal destek kullanımı yöntemlerine başvurulmuştur. İşlevsel olmayan başa çıkma yöntemlerinden ise en fazla davranışsal boş verme ve zihinsel boş verme yöntemlerine başvurulmuştur.

Sonuçlara karışık alt alanlar olarak bakıldığında en fazla kullanılan 3 yöntem; aktif başa çıkma, kabullenme ve yararlı sosyal destek kullanımı olurken en az kullanılan 3 yöntem; madde kullanımı, şaka/ mizah kullanımı ve inkar olmuştur.

Annelerin en fazla sorun yaşadığı iki alandan biri olan psikolojik alanda en fazla başvurduğu başa çıkma yöntemleri; kabullenme, duygusal destek kullanımı ve dini olarak başa çıkma olurken, eğitim alanında ise en çok başvurulan yöntemler; aktif başa çıkma, yararlı sosyal destek kullanımı, diğer meşguliyetleri bastırma ve geri durma olmuştur. Ekonomik sorunlarda en fazla kullanılan başa çıkma yöntemleri aktif başa çıkma, yararlı sosyal destek kullanımı ve diğer meşguliyetleri bastırma olmuştur. Eş ve diğer çocuklarla olan sorunlarda en fazla kullanılan başa çıkma yöntemleri ise kabullenme, yararlı sosyal destek kullanımı olmuştur. Annenin çevre ile olan sorunlarıyla baş ederken kullandığı yöntemler ise daha çok kabullenme, dini olarak başa çıkma, yararlı sosyal destek kullanımı ve zihinsel boş verme olmuştur.

Sonuçlara farklı bir açıdan bakıldığında annelerin psikolojik, aile içi ilişkiler ve çevre ile ilişkiler gibi psikolojik ve sosyal problemlere duygu odaklı başa çıkma yöntemleri ile yanıt verdikleri görülmüş, daha çok dişsal ve maddi kaynaklarla ilgili olan eğitim ve ekonomik sorunlarla problem odaklı yöntemlerle başa çıkmaya çalıştıkları görülmüştür. $\mathrm{Bu}$ sonuç; bireyin kontrol edebildiği durumlar için problem odaklı başa çıkmanın, kontrol edemediği durumlar için ise duygu odaklı başa çıkmanın daha yararlı olduğu ile ilgili teorik açıklamalarla uyumludur (Lazarus ve Folkman, 1984).

\section{Sonuç ve Öneriler}

Görüşmeler sonucunda elde edilen verilere göre anneler en çok psikolojik ve eğitim alanı ile ilgili sorun yaşamakta, en az yakın çevre ile ilgili sorun yaşamaktadırlar. Yaşanan psikolojik güçlükler üzüntü, sıkıntı, stres, şaşırma, şok, kabullenmeme, belirsizlik, bilgisizlik, gelecek kaygısı ve kendini sorumlu tutma şeklinde sıralanmaktadır. Anneler psikolojik sorunları ile ilgili olarak en çok duygu odaklı başa çıkma yöntemlerini kullanmaktadırlar. $\mathrm{Bu}$ yöntemler; kabullenme, duygusal destek kullanımı ve dini olarak başa çıkmadır. 
Annelerin ikinci sırada sorun yaşadığı problem alanı eğitimle ilgili sorunlardır. Bunlar; okul ve öğretmen sayısı yetersizliği, olumsuz öğretmen tutumları, normal okullarda kabul sorunları yaşama, bilgisizlik, farklı eğitim olanaklarının olmaması, sağlık sorunlarının eğitimi aksatması ve okulun eve uzak olmasıdır. Anneler eğitimle ilgili sorunlarını en çok problem odaklı başa çıkma yöntemleri ile çözmeye çalışmışlardır. Bu yöntemler; aktif başa çıkma, yararlı sosyal destek kullanımı, diğer meşguliyetleri bastırma ve geri durmadır.

Ekonomik güçlükler annelerin sorun yaşadığ1 üçüncü alan olmuştur. Bu alanda yaşanan güçlükler; sağlı harcamaları, bez bakım giysi masrafları, ek destek eğitim harcamaları, Türkiye'den alınan hizmetlerin -yol, sağlık, ikamet etmemasrafları, yol ve ulaşım masrafları, maaş bağlanmaması, çocuktan dolayı çalışamamadır. Ekonomik sorunlarla problem odaklı yöntemlerle baş edildiği görülmüştür. Bunlar; aktif başa çıkma, yararlı sosyal destek kullanımı ve diğer meşguliyetleri bastırmadır.

Annelerin sorun yaşadığı dördüncü alan eş ve diğer çocuklarıyla yaşadıkları güçlükler olmuştur. Bu alandaki sorunları şöyle belirtmişlerdir; eşin ilgisizliği ve çocuğu reddetmesi, kardeş kıskançlı̆̆ı, kardeş ile geçimsizlik, eşlerin birbirini suçlaması. Bu sorunlarla nasıl baş ettiklerine gelince genel olarak kabullenme ve duygusal destek kullanımı gibi duygu odaklı baş etme yöntemlerini kullandıkları, bunun yanında alt yöntemlere bakıldığında problem odaklı başa çıkma yöntemleri olan yararlı sosyal destek kullanımı ve aktif başa çıkma yöntemlerini de kullandıkları görülmüştür.

Annelerin en düşük seviyede sorun yaşadıklarını bildirdikleri alan yakın arkadaş ve akrabalarla yaşanan sorunlardır. Bu alanda sosyal çevrenin azalması, kaynana tarafindan suçlanma ve çocuğun reddedilmesi ve çevrenin anlayışsızlığı gibi güçlükler yaşamaktadırlar. Başa çıkma yöntemleri sorulduğunda genel olarak duygu odaklı yöntemler kullandıkları görülmüş, alt yöntemler olarak kabullenme, dini olarak başa çıkma yöntemlerini kullandıkları sonucuna ulaşılmıştır. Bunun yanında problem odaklı yöntemlerden olan yararlı sosyal destek kullanımı ve işlevsel olmayan bir yöntem olan zihinsel boş verme yöntemini de çok kullandıkları görülmüştür.

Başa çıkma ile ilgili yapılmış analiz sonuçlarına göre anneler en çok problem odaklı başa çıkma yöntemlerini kullanmakta sonra sırasıyla duygu odaklı ve işlevsel olmayan yöntemleri kullanmaktadırlar. Anne babalarla benzer konuda yapılmış bir araştırmada da başa çıkma yöntemlerinden en fazla problem çözmeye dayalı yöntemin kullanıldığı görülmüştür (Öz, 2018). Yaşanan sorun alanlarına göre kullanılan başa çıkma yöntemi farklılaşmaktadır. Problem odaklı yöntemler en çok ekonomik ve eğitim ile ilgili sorunlarda kullanılmakta, duygu odaklı başa çıkma yöntemleri ise en çok psikolojik güçlükler ve aile içi (eş ve diğer çocuklar) sorunlarda kullanılmaktadır.

En çok kullanılan problem odaklı başa çıkma yöntemleri; aktif başa çıkma ve yararlı sosyal destek kullanımı iken, en çok kullanılan duygu odaklı başa çıkma yöntemleri kabullenme ve duygusal destek kullanımı olmuştur.
Işıkhan (2005a) zihinsel yetersizliği olan çocuğa sahip annelerin en fazla psikolojik ve ekonomik sorunlar yaşadığını belirlemiştir. Bu araştırmada ise psikolojik, eğitimle ilgili ve ekonomik sorunlar en çok yaşanan sorunlar olarak görülmüştür. Bu bakımdan bu araştırmanın sonuçları ilgili araştırma ile paralel bulunmuştur.

Yararlı sosyal destek kullanımı, annelerin üçüncü sırada kullandığı başa çıkma yöntemi olmuştur. Anneler yakın çevresinden bilgi, destek ya da tavsiye yardımı almayı yaygın bir yöntem olarak tercih etmişlerdir. Seltzer ve Fussell ve Krauss (1989) 'un yürüttüğü bir araştırmaya göre annenin sosyal çevresi annenin yaşam kalitesini belirlemede resmi destekten daha iyi bir belirleyici görevi görmektedir. Bir diğer araştırmada annenin yakın çevresinden gelen psikososyal destek; annenin yetersizliğe sahip çocuğunu kabul etmesinde ve annenin özel eğitim hizmetlerinde karşılaştığı sorunları aşabilmesinde yardımcı bir etken olarak açıklanmıştır (Deniz, Dilmaç ve Arıcak, 2009).

Annelerden 4'ü eğitimle ilgili bilgisizlik yaşamasını bir sorun olarak bildirmiştir. Bazıları özel eğitim kurumlarını tanımamakta, yerini bilmemekte, bazen gittikleri uzak kurumdan kendi evlerine yakın bir kurum olduğunu duyduklarını, bu nedenle çocuklarının eğitimlerinin, bilhassa tanının hemen ertesinde alacağı eğitimin sekteye uğradığını belirtmişlerdir. Bu konuyla ilgili yapılan bir incelemede de anneler; çocukları için erken çocukluk özel eğitim hizmetlerinde doğru bilgiye erişimde güçlük yaşadıklarını bildirmişler, kaynağı belli olmayan bilgilerle hareket ettiklerini ve bilgilerin çok dağınık olduğunu söylemişlerdir (Yıldırım, Akçamete, 2014). Özellikle erken çocukluk çağında özel eğitim hizmeti gerektiği durumlarda, annelerin bilgisizlik yaşamasının kendilerini engelleyici bir etmen olduğu söylenebilir.

Ayyıldız, Şener, Kulakçı ve Veren (2012), yaptıkları araştırmada zihinsel yetersizliği olan çocukların anneleri \%62,4'ü toplumun bakış açısından rahatsızlık duyduğunu, sosyal çevresiyle iletişimde zorluk yaşadığını belirtmiştir. Bu araştırmada annelerin \%40’1 yakın çevre ile ilgili sorunlar yaşadığını bildirmiştir. Fakat bu araştırmada çevre ile ilgili sorular yakın, akraba, komşu, arkadaş gibi geniş bir grubu temsil etmektedir. Annenin yaşadığı toplumsal sıkıntılar olarak bakıldığında sadece 1 anne "çevrenin anlayışsızlığı" kodlamasına giren bir yanıt vermiştir. Diğer 14 anne çevrenin tutum ve davranışları ile bir şekilde baş ettiklerini, kendilerini rahatsız edecek fazla bir şey olmadığını belirtmişlerdir. Anneler genelde destek ve yardım gördüklerini, anlayışla karşılandıklarını, kısa açıklamaların yapılması durumunda yararlı dönütler aldıklarını veya bazı rahatsız edici davranışlarla karşılaşsalar da bunların yok sayılabilir düzeyde olduğunu belirtmişlerdir. Ayyıldız vd. (2012) yaptığı araştırmaya göre toplumun bakış açısından rahatsız olmayan annelerin etkili baş etme yöntemlerini kullandıkları görülmüştür. Bu araştırmada annelerin çoğu toplumun bakış açısından rahatsızlık belirtmemişlerdir ve yaklaşık \%90’1 işlevsel başa çıkma yöntemleri kullanmışlardır. (Tablo 3.7) Bu bakımdan Ayyıldız vd. (2012)'nin bulguları ile paralel sonuçlar elde edilmiştir.

$\mathrm{Bu}$ araştırmada elde edilen veriler yakın çevreden destek görmeme sorununa işaret eden bazı araştırma sonuçları ile farkl111k göstermektedir (Kurt, Tekin, Koçak, Kaya, Özpulat, 
ve Önatb 2008; Kaytez, Durualp ve Kadan, 2015; Özsoy, Özkahraman ve Çallı, 2006). Annelerin 3'ü sosyal çevrelerinin azaldığını ve 1 tanesi çevreyi anlayışsız bulduğunu ifade etmiş fakat bunun dışında özellikle geniş ailelerinden, kendi anne baba ve kardeşlerinden önemli oranda destek gördüklerini belirtmişlerdir. Bu araştırmadaki veliler sosyal destek görmeme üzerine başkaca bir sorun bildirmemişlerdir.

Annelerin kullandığı başa çıkma yöntemlerinden olan yararlı sosyal destek kullanımı ve dini başa çıkmanın alandaki diğer araştırmalardaki sonuçlarla benzerlik gösterdiği görülmüştür (Şengül ve Baykan, 2013; Doğan 2016).

Yaşanan sorunların psikolojik, eğitimle ilgili sorunlar, ekonomik sorunlar, eș ve diğer çocuklarla yaşanan sorunlar ve yakın arkadaş, akraba ve çevre ile ilgili sorunlar başlığı altında araştırıldığı bu araştırmada zihinsel yetersizliği olan çocukların annelerinin en çok psikolojik ve eğitimle ilgili alanlarda sorun yaşadıkları görülmüştür. Anneler yaşadıkları sorun alanları en çok problem odaklı başa çıkma yöntemlerine başvurarak çözmeye çalışmaktadır. Problem odaklı başa çıkma yöntemi olarak en çok aktif başa çıkma ve yararlı sosyal destek kullanımı kullanılırken, duygu odaklı başa çıkma yöntemlerinden kabullenme ve duygusal destek kullanımı kullanılmıştır.

Elde edilen sonuçlar 1şı ğında annelerin yaşanan sorunlarla daha aktif başa çıkabilmeleri için halıhazırda kullandıkları çözüm yollarını geliştirmelerine yardımcı olunması, yararlı sosyal destek kullanım araçlarının geliştirilmesi, eğitimle ilgili yaşanan sorunlarda kaynak geliştirme ve farkındalığa yönelik çalışmaların artırılması, annelerin tanılama sürecinden itibaren başvurabilecekleri psikolojik yardım kanallarının artırılması gibi önerilerde bulunulmuştur.

\section{Kaynakça}

Akandere, M., Acar, M. ve Baştuğ, G. (2009). Zihinsel ve fiziksel engelli çocuğa sahip anne ve babaların yaşam doyumu ve umutsuzluk düzeylerinin incelenmesi. Selçuk Üniversitesi Sosyal Bilimler Enstitüsü Dergisi, 22, 23-32.

Altunışık, R., Coşkun, R., Bayraktaroğlu, S., \& Yıldırım, E. (2010). Sosyal Bilimlerde Araştırma Yöntemleri SPSS Uygulamalı (6. Bask1). Sakarya: Sakarya Yayıncılık.

Ayyıldız, T., Şener, D. K., Kulakçı, H. ve Veren, F. (2012). Zihinsel engelli çocuğa sahip annelerin stresle baş etme yöntemlerinin değerlendirilmesi. Ankara Sağlık Hizmetleri Dergisi, 11(2), 1-12.

Çengelci, B. (2009). Otizm ve down sendromlu çocuğa sahip annelerin kaygı umutsuzluk ve tükenmişlik duygularının karşılaştırılması. Ege Eğitim Dergisi, 10(2), 1-23.

Demir, G., Özcan, A. ve K1zılırmak, A. (2010). Zihinsel engelli çocuğa sahip annelerin depresyon düzeylerinin belirlenmesi. Anadolu Hemşirelik ve Sağlık Bilimleri Dergisi,13(4), 53-58.

Deniz, M. E. (2006). The Relationships among coping with stress, life satisfaction, decision making styles and decision self-esteem: An Investigation on Turkish university students. Social Behavior and Personality: An International Journal, 34(9), 1161-1170.

Deniz, M.E., Dilmaç, B. ve Arıcak, O.T. (2009). Engelli çocuğa sahip olan ebeveynlerin durumluk-sürekli kayg1 ve yaşam doyumlarının incelenmesi. Uluslararası Insan Bilimleri Dergisi. 6: 1. sf. 954-968.

Doğan, M. (2001). İşitme Engelli Çocuğa Sahip Ebeveynlerin Çeşitli Psikolojik Değişkenler Açısından Değerlendirilmesi. Yüksek Lisans Tezi. Ankara: Ankara Üniversitesi (yayımlanmamış).

Dönmez, N., Bayhan, P. ve Artan, İ. (2000). Engelli çocuğa sahip ailelerin beklentileri ve endişe duydukları konuların incelenmesi. Sosyal Hizmetler Dergisi, 1(11), 16-23.

Fussell, S.R., ve Krauss, R.M. (1989). The effects of intended audience on message production and comprehension: Reference in a common ground framework. Jurnal of Experiental Social Psychology, 25,203-219.

Hedov, G., Annerén, G. ve Wikblad, K. (2000). Selfperceived health in swedish parents of children with down's syndrome. Quality of Life Research, 9(4), 415422 .

Işıkhan, V. (2005a). Zihinsel engelli çocuğa sahip annelerin psiko-sosyal ve sosyoekonomik sorunları. Toplum ve Sosyal Hizmet Dergisi, 16(2), 35-50.

Kaçan-Softa, H. (2013). Engelli çocuğa sahip ebeveynlerin depresyon düzeylerinin incelenmesi. Kastamonu Ĕgitim Dergisi, 21(2): 589-600.

Kaner, S. (2004). Engelli Çocukları Olan Ana Babaların Alglladiklarl Stres, Sosyal Destek ve Yaşam Doyumlarının Incelenmesi, Bilimsel araştırma projesi kesin raporu. Ankara: Ankara Üniversitesi.

Kaytez, N., Durualp, E. ve Kadan, G. (2015). Engelli çocuğu olan ailelerin gereksinimlerinin ve stres düzeylerinin incelenmesi. Journal of Research In Education and Teaching, 4(1).

Keskin, G., Bilge, A., Engin, E. ve Dülgerler, Ş. (2012). Zihinsel engelli çocuğu olan anne babaların kaygı, annebaba tutumları ve başa çıkma stratejileri açısından değerlendirilmesi. Anatolian Journal of Psychiatry, 11, 30-37.

Köksal, G. (2011). Zihinsel Engelli Çocuklart Olan Ebeveynlerin Yaşamlarında Alglladikları Stresi Yordayan Faktörlerin İncelenmesi. Yüksek Lisans Tezi, Dokuz Eylül Üniversitesi, İzmir.

Kurt, A. S., Tekin, A., Koçak, V., Kaya, Y., Özpulat, Ö. ve Önat, H. (2008). Zihinsel engelli çocuğa sahip anne babaların karşılaştıkları güçlükler. Turkiye Klinikleri Journal of Pediatrics, 17(3), 158-163.

Lazarus, R.S. ve Folkman, S. (1984). Stress, Appraisal and Coping, (1st ed), New York: Springer Publishing Company. 
Meirsschaut, M., Roeyers, H. ve Warreyn, P. (2010). Parenting in families with a child with autism spectrum disorder and a typically developing child: Mothers' experiences and cognitions. Research in Autism Spectrum Disorders, 4, 661-669.

Öz, Z. (2018). Engelli Çocuğu Olan Anne-Babaların Kaygl Düzeyi ve Başa Çıkma Stratejilerinin Değerlendirilmesi. Yüksek Lisans Tezi, Üsküdar Üniversitesi.

Özsoy, S. A., Özkahraman, A. G. Ş. ve Çallı, Y. H. F. (2006). Zihinsel engelli çocuk sahibi ailelerin yaşadıkları güçlüklerin incelenmesi. Sosyal Politika Çalışmaları Dergisi, 9(9).

Rowbotham, M., Carroll, A. ve Cuskelly, M. (2011). Mothers' and fathers' roles in caring for an adult child with an intellectual disability. International Journal of Disability, Development and Education, 58 (3), 223-240.

Şengül, S. ve Baykan, H. (2013). Zihinsel engelli çocukların annelerinde depresyon, anksiyete ve stresle başa çıkma tutumlar1. Kocatepe Tip Dergisi,14(1).
Uğuz, Ş., Toros, F., İnanç, B. Y. ve Çolakkadıoğlu, O. (2004). Zihinsel ve/veya bedensel engelli çocukların annelerinin anksiyete, depresyon ve stres düzeylerinin belirlenmesi. Klinik Psikiyatri, 7(1), 42-7.

Üskün, E.,ve Gündoğar, D. (2010). The levels of stress, depression and anxiety of parents of disabled children in Turkey, Disability and Rehabilitation, 32 (23), 19171927.

Yıldırım, E. ve Akçamete, G. (2014). Determination of difficulties encountered by mothers having children with multiple disabilities during early childhood special education services process. Cumhuriyet Uluslararas1 Eğitim Dergisi, 3 (1), 74-89. DOI: 10.30703/cije.321336

Yıldırım, A. ve Şimşek H. (2004). Sosyal Bilimlerde Nitel Araştırma Yöntemleri. Ankara: Seçkin Yayıncılık

Zembat, R. ve Yildiz, D. (2010). A comparison of acceptance and hopelessness levels of disabled preschool children's mothers. Social and Behavioral Science, 2,1457-146 